\title{
The Changes of Mao Zedong Thoughts on Women's Liberation after the Founding of People's Republic of China
}

\author{
Chang Sun \\ (China University of Geosciences, Beijing, 100083)
}

\begin{abstract}
:
Mao Zedong Thought on Women's Liberation after the founding of People 's Republic of China in an important part of the women's movement, and has significantly differences to the Thought before the founding. It mainly reflects three aspects: changes in the importance of women's liberation, changes in realized methods, and changes in the relationship between women's liberation and social liberation, which is pay more attention to women's participation in labor production, more attention to women's liberation from many sense of wake up and pay more attention to women's liberation go into social liberation. This longitudinal comparative analysis can be more clearly show Mao Zedong Women's Liberation in its entirety, and we can fully understand Mao Zedong and the impact of changes in Women's Liberation. For our present stage of women's work, it provides a useful reference particularly for the women's liberation consciousness of self-respect.
\end{abstract}

Key words: Changes; After the founding of China; Mao Zedong Thought on Women's Liberation

As a pioneer of Chinese women's movement, Mao Zedong combined Marxist theory on women's liberation with the reality of China. He revealed the root of Chinese women's issue is the class oppression, analyzed the importance of women's liberation, organizational forms and other issues. He led Chinese women overthrew the feudal patriarchal system and the rule of the exploiting classes. Further more, in socialist construction period Mao Zedong explored Chinese women's real liberation. Women's liberation movement around the center of the party and state work is in full swing. With the changes of history, Mao's women liberation thought reflects different emphases. If women's liberation before the founding is local, formal liberation, then after the founding Mao's thought in women's liberation towards more comprehensive and far-reaching direction.

\section{Logical Stating Point - the change in \\ knowledge of the nature of women's \\ liberation}

As early as 1927 Mao Zedong in Hunan rural areas survey pointed out that Chinese women are bound by four great rope, namely authority of political, patriarchal, theocratic and husband which represents the entire feudal patriarchal ideas and institutions. Fundamentally speaking, the nature of Chinese women's issue was the class oppression. The only way to destroy the bound was break the four ropes and actively participate in the revolution. In the first revolutionary war, the land revolution, the anti-Japanese War, Chinese women as a "a power which can determine victory or defeat of the revolution" has played an important role and made a great contribution. After the founding of People's Republic of China, the world situation, country conditions and 
domestic people have undergone great changes. Firstly, the establishment of China is conducive to maintaining a relatively stable external environment. Especially the establishment of diplomatic relations with the Soviet Union at the economic, political and cultural aspects also provides a useful reference for the Chinese women's liberation. Secondly, the Chinese victory in the struggle against imperialism and feudalism class changed the structure of Chinese society and central tasks. The principal contradiction in our society has changed for the people's material and cultural needs and the contradiction between the productive forces backward, and then the nature of women's issues will be a corresponding change. Thirdly, the Chinese women claimed their rights and development. After the baptism of war, China won the women's physical and ideological emancipation, in the course of socialist construction, women should also be able to defend their rights and give full play to the initiative.

Therefore, the essence of after the founding of China Mao's thought of women's liberation is as he did in "businessmen should control their own destiny" mentioned in the article: "Discrimination against women, pay no attention to women, these phenomenon should get rid of in the process of building socialism." (1) Development of production is an important part of building socialism, mobilized women to participate in productive activities is the way to improve women's economic and political status also the basic condition for the liberation of women. In this process, women, through their own efforts to win the respect of others, and laid the same position with men in society. Mao Zedong said: "Chinese women are a great resources and must be explore this resource in order to build a great socialist country." (2) After the founding of China, the importance of women's liberation is that women as great human resources, women's issues should be resolved around the state building in the center to expand. The reasons for the oppression of women linked with social production, which is after founding of China Mao's thought on women's liberation is the logical starting point but also the women's liberation movement is an important basis for policy formulation.

\section{Important Contents — the changes of women's liberation approaches}

Understanding the nature of women's liberation would inevitably lead to changes in women's liberation ways transformation. After the founding of China, Mao closely linked the women's liberation with the nation-building. In the substantive level, Mao mobilized women's participation in social production, participation in political and economic activities; In the institutional level, the rights of women to be legal safeguards, with particular attention to the practical implementation of the law; In the ideological level, Mao was trying to shape a new image of women; In the measures level, Mao implemented a series of measures to reduce the burden of women in the family.

\subsection{Encouraging rural, urban women's participation in social labor}

The establishment of public economy expanded first in rural areas. Land allocation is the most important task in rural areas, land reform in the country since the fall of 1950 be fully implemented, and the allocation principles is equality in the gender. Rural women have become the owner of the land and means of production, and achieved the basic conditions for economic rights, on this basis, women can be achieved political, economic, family status improved. In Mao's "women embarked on the labor front," a text notes that: "In order to build a great socialist 
society, mobilize the broad masses of women to participate in productive activities, has great significance. ${ }^{(3)}$ In the cities, more and more women are also involved in the construction of socialist industrialization ranks. Deployment of national labor policy to allow more women into the industrial production field of which some of the women had never before set foot in, but also have a female figure. For example, China's female pilots, female train drivers, female tractor driver etc appear in this period.

\subsection{Law enforcement to promote the realization of gender equality}

May 1, 1950, the Central People's Government promulgated the "Marriage Law", which is issued the first important law after the founding of China. "Marriage Law" follows the principle of equality between the sexes, in which two important aims are to abolish the feudal marriage system and implement of democratic institution of marriage and marital autonomy. Gender equality as a national legal form is Chinese women's liberation big step forward. Mao as done a lot of work for the drafting of the law which has fundamental interests of women in relation to, but has repeatedly stressed that the legal provisions in line with the actual work of the gap, he said: "Some legal provisions to be truly implemented need a few years. As many of the provisions of the Marriage Law is with programmatic, to thoroughly implement at least three five-year plans. "(4) This suggests that Mao hasn't cared about the rights of women which laws regulated, but in reality these women can really be the owner of the rights. The law does not simply rely on the implementation of a mandatory regime, also need to enhance women's self-awareness.

\subsection{Encouraging women to create a new image}

In feudal shackles women to survive due to economic independence only rely on men, they are typically existed as "the second sex". Mao Zedong hated this traditional image. After the founding of China, Chinese women in the economic, political and social status has a lot of progress, Mao tried to establish a new system image of women, this image symbolizes a break with the past feudal thinking, not just in appearance, more importantly, a new attempt of shaping in the heart. The shape of the image of women and men is the intrinsic qualities gradually fused together. The new era of Mao Zedong in mind women are completely different with the traditional women that he expected women to like men as separate individual existence, abandon the feudal period trite, shackles in the construction of socialism as to realize their value. By 1964, Mao Zedong was exclaimed: "Times have changed, men and women are same, men can do things women can do the same." (5) This is a Chinese traditional male-female relationships subversive challenge, completely changed the ability of social awareness for women, the equivalent of a female spirit of the world revolution.

\subsection{Reduce the burden on women's family}

Responsibility of women in the family can be divided into two main areas: procreation and maintenance of the daily household running. Both accounted for the vast majority of women to a life time. After the founding of China, women in order to enable more of them to participate in the building of socialism, a series of women maternity, child rearing, housework problem is referred to the agenda. Mao Zedong said: "The couple should be worked out a family plan provides a lifetime how many children born. This plan should coordinate with the national five-year plan together." ${ }^{\circledR}$ This is the party and the country's top leaders first mention and the idea of family planning, Mao Zedong recognized population issues will be an 
important limiting factor in the development of production, control of human production itself is a valid approach. In order to reduce women's burden of domestic work, the establishment of public canteens, kindergartens is an effective way. The early founding of public canteens and nurseries career gained rapid development. Some of these measures partly changes in women's status in traditional family, to promote birth control can effectively reduce the burden on women, housework is not just the women's fair share of things, and even change the traditional gender division of labor.

\section{Tortuous Exploration- the changes on the relations between women's liberation and social liberation}

As early as 1939, Mao Zedong profoundly expounded relationship between emancipation of women and the social liberation, he said: "Obviously, women's liberation and social emancipation is closely linked with, the women's liberation movement should become an integral part of the liberation movement. ...... so, to really seek social liberation, we must mobilize the broad masses of women to participate; Similarly, to truly seek their own liberation of women, the women will have to participate in social liberation struggle. "(7) This describes the two main ideas of Mao Zedong, first women's liberation and social emancipation are dialectically linked, second women to participate as a subject of social liberation to realize their own liberation. But after the founding, especially after 1957, Anti-rightist struggle enlargement changed the principal contradiction domestic judgments. Mao Zedong put forward the Third Plenum of the CPC eighth, the contradiction between the proletariat and the bourgeoisie is currently the principal contradiction in Chinese society, coupled with the Great Leap Forward, communes appear does not really solve the problem of "leftist" trend. Out of the overall strategy of Mao Zedong Thought, that social emancipation compared with women's emancipation is the premise. There is no social liberation; women are also not completely liberated. Women's liberation and social emancipation relationship has changed. The emancipation of women in a subordinate position completely.

Fundamentally speaking, the people's commune is the subjective overestimation of agricultural economic development of the product, in this process, most of the women were mobilized into the production front. The reality is that the party generated impetuosity sharp swell, public canteens free, childcare built in one night, women meet the complete liberation these unreal things are more and more serious. Women's education problems are also linked with social liberation. Mao Zedong believed that schooling can be shortened. This kind of education system will inevitably lead to the increase of female drop-out rates, increasing the proportion of female illiteracy, is not conducive to the physical and mental development of young students at that time.

It should be noted that, Mao Zedong for women's liberation and social emancipation relations thinking in terms of attitude is absolutely sincere, and has also taken a series of measures to achieve the complete emancipation of women, to achieve the ideal of communism. And it is complicated situation at home and abroad, and his desire to develop high-speed collision of frustration, making him all kinds of contradictory judgments error occurred, ignoring the real productive forces development situation, and also ignoring the relationship between women's liberation and social emancipation further thinking. 


\section{Conclusion}

In short, after the founding of China, Mao Zedong's women liberation thought is based on China national conditions as the basis for the theoretical guidance of Marxism-Leninism. Socialism institutionally established in a series of measures to protect women's rights. Gender equality as a starting point to it, around the production activities in all fields of socialist construction commenced. Social liberation does not mean the complete emancipation of women, because women are oppressed status is not established as a result of class society, and will not end because of the disappearance of class society. Women's liberation task is arduous and long-term that we should always bear this in mind.

\section{References}

[1] Mao Zedong. (2009)Mao Zedong collected works Vol.6 (Beijing, People's Publishing House).

[2] Mao Zedong. (1997)Mao Zedong Manuscripts after the Founding of China Vol.5 (Beijing, Central Literature Publishing House).

[3] Mao Zedong. (1997)Mao Zedong Manuscripts after the Founding of China Vol.5 (Beijing, Central Literature Publishing House).

[4] Mao Zedong. (1997)Mao Zedong Manuscripts after the Founding of China Vol.4 (Beijing, Central Literature Publishing House).

[5] Mao Zedong. (1978) Chairman Mao Zedong on Women(Beijing, People's Publishing House).

[6] Mao Zedong. (2009)Mao Zedong collected works Vol.7 (Beijing, People's Publishing House).

[7] Mao Zedong. (2009)Mao Zedong collected works Vol.2 (Beijing, People's Publishing House). 